ISSN: $1130-3743$ - e-ISSN: 2386-5660

DOI: http://dx.doi.org/10.14201/teoredu20162816182

\title{
UNIVERSITY AND DELIBERATIVE DEMOCRACY. TOWARDS CITIZENSHIP EDUCATION
}

\author{
Universidad y democracia deliberativa. Hacia una \\ educación para la ciudadanía
}

\section{Université et démocratie délibérative. Pour une éducation à la citoyenneté}

\author{
Paolo SCOTTON \\ IMT Institute for Advanced Studies Lucca. Piazza San Ponziano, 6. \\ 55100 Lucca-Italy.paolo.scotton@imtlucca.it
}

Fecha de recepción: enero de 2016

Fecha de aceptación: marzo de 2016

SUMMARY

Deliberative democracy represents one of the most relevant political theories and it has acquired a growing importance within political debates and practices. However it presents some crucial problems in relation to the very high standards of rationality required to citizens for the deliberative process, in particular regarding the problem of public ignorance and the capabilities' deficit. Amid these problems this article argues in favour of the necessity of education to political life as an unavoidable precondition for deliberative democracy. Since the theory is mainly concerned with the participation of adults within society, the task of offering possible solutions to these questions evidently stands on the shoulders of university education. The article calls for a fundamental ethical and social role of university within society without which the gap between the abstract theory of deliberative democracy and its real practices would determine its complete rejection and any form of democratic participation would ultimately be meaningless, if not dangerous. 
Key words: deliberative democracy; rationality; education; university; society.

\section{RESUMEN}

La democracia deliberativa representa una de las más relevantes teorías políticas y ha adquirido una importancia creciente dentro de los debates y las prácticas políticas. Sin embargo, esta teoría presenta algunos problemas esenciales en relación con los estándares de racionalidad muy elevados que requiere en los ciudadanos para que el proceso deliberativo tenga lugar, en particular los relacionados con la cuestión de la ignorancia pública y del deficit de capacidades. Este artículo plantea la necesidad de la educación para la vida política como prerrequisito fundamental para la democracia deliberativa. Debido al hecho de que esta teoría se enfoca principalmente en la participación de los adultos en la política, la tarea de ofrecer posibles soluciones a estas cuestiones se echa sobre las espaldas de la educación universitaria. El artículo incita a un fundamental papel ético y social de la universidad dentro de la sociedad sin el cual la discrepancia entre la teoría de la democracia deliberativa y sus prácticas determinaría su completo rechazo. Además, cualquier forma de participación democratica acabaría careciendo de sentido y, más aún, perjudicial.

Palabras clave: democracia deliberativa; racionalidad; educación; universidad; sociedad.

\section{SOMMAIRE}

La démocratie délibérative représente une des théories politiques les plus importantes et il a acquis une importance croissante dans des débats et des pratiques politiques. Cependant, cette théorie présente quelques problèmes cruciaux en relacion aux standards de rationalité très élevées exigée aux citoyens pour le procès délibératif, en particulier liée à la question de l'ignorance publique et du déficit des capacités. Cet article soutient la nécessité de la éducation politique comme condition préalable fondamentale pour la démocratie délibérative. Car cette théorie se concentre principalement sur la participation des adultes à la vie politique, la tâche de proposer des solutions à ces questions est debout sur les épaules de l'enseignement universitaire. Pour ces raisons, l'article appelle à un rôle éthique fondamental de l'université dans la société sans laquelle l'écart entre la théorie de la démocratie délibérative et ses pratiques déterminerait son rejet complet. De plus, tous les types de participation démocratique seraient en fin de compte vides de sens, et encoure plus, dangereux.

Mots clés: démocratie délibérative; rationalité; éducation; université; société. 


\section{INTRODUCTION}

In recent decades it has been made an evident and important detour in political theory and social sciences towards the study of forms of empowered democracies. Since the pioneering works of Carole Pateman $(1970,2012)$ on the importance of fostering participation for contributing to a genuine democratisation of our societies these theories have acquired an outstanding importance which, for instance, have brought John Dryzek to refer to deliberative democracy as «the most active area of political theory in its entirety (not just democratic theory)» (Dryzek, 2007, 237). Even if, on the one hand, this tendency has contributed to positively thicken the concept of democracy and to call for the concrete implementation of citizen's governance, on the other it has also taken for granted the suitability of its realisation, without questioning in-depth its own premises. For instance, it is evidently true, as James Fishkin put it, that "democracy is more meaningful if citizens are better informed and more attentive to the issues they are voting on» (Fishkin, 2002, 225). Yet, what appears more problematic than what most of these theorists think is the fact that this political consciousness cannot substantially be a product of deliberative democracy, but rather its very precondition. Put it differently, several deliberative democrats often forget what the famous pedagogue John Dewey clearly and powerfully wrote almost a century ago in his famous book entitled Democracy and Education (Dewey, 2008, 3): "Beings who are born not only unaware of, but quite indifferent to, the aims and habits of the social group have to be rendered cognizant of them and actively interested. Education, and education alone, spans the gap». Obviously, the kind of democracy Dewey had in mind and, consequently, the education he proposed are significantly different in comparison with current participatory models. However, the lack of attention towards the importance of education within political theory still continues to be extremely relevant as Axel Honneth, for instance, has recently underlined ${ }^{1}$. This fact is even more astonishing if we consider the extremely high level of mass education currently reached within European countries where, according to Eurostat, in 2013 approximately $75 \%$ of the people aged 24-65 do possess a secondary or tertiary education ${ }^{2}$. In this scenario it is therefore necessary to comprehend not only the reasons why education is actually necessary for any theory of empowered democracy but also, and more importantly, what kind of education should be foster for this purpose.

Both of these aspects can fruitfully be studied by analysing some problems which derive from a total or partial lack of adequate education in relation to the

1. "La teoría de la democracia, en sus numerosas formas y voces, actualmente suele guardar silencio sobre el lado educativo del asunto que le compete; en ella hoy en día no se encuentran reflexiones ni sobre los métodos de enseñanza ni sobre el plan de estudios; la idea de que una democracia viva debe crear continuamente sus propias condiciones de existencia, culturales y morales, a través de procesos educativos generales, entre tanto, se le ha extraviado a la Filosofía polítican (HONNETH, 2013, 379).

2. See the tables reported by Eurostat at http://ec.europa.eu/eurostat/web/education-and-training/ data/main-tables. 
theory of deliberative democracy. In particular, two very powerful but often dismissed criticisms have been explicitly or implicitly moved against this theory conceived as systematic model for managing political issues. Both of them are related to the significant standards of rationality which the theory requires to all the participants in the deliberative process. These criticisms -which have frequently been ignored by theorists of deliberative democracy- directly question the very kernel of the theory in a way which, as will be proved, can thoroughly invalidate it. The first of these criticisms has been labelled as the "public ignorance question" whereas the second, strictly related to the previous one, will be defined in this article as the "abilities' deficit». They both derive from the very definition of deliberative democracy and, in particular, from the nature of the rational process which is deemed to render possible a meaningful deliberation. However, in spite of their common origin, they represent two different problems which, consequently, have to be considered separately insofar as the first is related to the way in which rationality is built, whereas the second to the way in which this very rationality comes to a proper expression within public debates and discourses. To understand the relevance of these criticisms it would evidently be necessary to provide (\$2) a definition and a brief discussion of the notion of deliberative democracy. After that, it would be possible to underline (§3) the necessary and often dismissed presuppositions implied by the theory in relation to citizens' rationality. This will be presented by highlighting the difficulties and biases in the theory that their underestimation produces. This presentation will permit to define the scopes and characteristics of the two criticisms, namely ( $\$ 4$ ) the "public ignorance question" and (\$5) the «abilities' deficit». To offer a response and solution to these criticisms first of all it will be stressed (\$6) the importance of education, in particular during the formal schooling period and the adult age through university and, also, via the media education. This discussion will permit to understand not only the ethical and political role played by university, but also to trace a path along which to define its educational programs. In fact, it will be shown how a form of education as the one suggested by the "capability approach" could meaningfully help the deliberative process, therefore indicating a line to be followed by university. Thus, this paper aims at highlighting the necessity of facing the problem of education within deliberative democracy so to better understand (\$7) the relation among the descriptive and normative aspects of this theory, and the role which university play or should play within society.

\section{DeFINING DELIBERATIVE DEMOCRACY}

Within the vast literature on DD it is difficult to find an undisputed definition of this theory, due to the very different conceptions of single influential authors in the field. To avoid any sort of partisanship, in this paper I will present a very minimum definition which can be generally accepted. For this purpose, I think it would be useful to quote a basic definition provided by Thompson and Gutmann (Thompson and Gutmann, 2004, 7) according to whom DD is: 
A form of government in which free and equal citizens (and their representatives) justify decisions in a process in which they give one another reasons that are mutually acceptable and generally accessible, with the aim of reaching conclusions that are binding in the present on all citizens but open to challenge in the future.

As this general definition exhibits, DD attributes a very important role to the process through which a decision is made and not only to the final outcome represented by the decision. In fact, a decision could merely be expressed by a vote or a preference, as in the classical theories of democracy ${ }^{3}$, without any need of justifying the choice. On the contrary, DD frequently faces "wicked problems" which do not imply only a "yes» or "no" opinion, as in the case of the "tame problems» which are typical of the rational choice scenario ${ }^{4}$. Indeed, DD concerns questions in which a moral, ethical or political disagreement is at stake and therefore the deliberation process requires an exhaustive discussion before reaching a consensus. In addition, the very nature of the theory presupposes that the general framework in which the deliberation takes place guarantees «an inclusive process of opinion and willformation ${ }^{5}$ where the debate is conducted in accordance to "the force of the better argument ${ }^{6}{ }^{6}$ with the aim of finding, thanks to an open and free discussion, possible solutions ${ }^{7}$. Moreover, it requires the process to be fair (i.e. brought about by free and equal persons) and regulated by a correct use of rational arguments, which have to be understandable by all the participants in the debate. As far as the scope of this deliberation process is concerned, either directly or indirectly, it is evident that if the decision is going to affect all the citizens, the larger the scope of deliberation the better ${ }^{8}$. The notion of equality deserves to be briefly specified. Indeed, it is evident that since the aim of DD is listening as many voices as possible to enrich the spectrum of opinions, this equality does not mean homogeneity, but rather equal ability to participate in the debate and fairness during the process of deliberation. The abovementioned definition clearly reveals that DD gives particular importance to an active and engaged participation ${ }^{9}$ of people in politics, considering citizens

3. For an introductory definition of the different models of democracy which have been developed in the history of Western thought see for instance SARTORI (1987); HELD (2006).

4. For this distinction see CARCASSON and SPRAIN (2012).

5. HABERMAS $(1998,241)$.

6. HABERMAS $(1975,108)$.

7. The "final cause" of this method could eventually be identified in different aims, for instance in an attempt to minimize moral dissent in a pluralist society (THOMPSON and GuTMANN, 2004; SEN, 2009; TALISSE, 2009) or to offer a proper legitimacy to modern democracy by enlarging the consensus (COHEN, 1997).

8. In fact: "What makes deliberative democracy democratic is an expansive definition of who is included in the process of deliberation" (THOMPSON and GUTMANN, 2004, 9). Indeed, it would seem paradoxical to think about a model such as that purported by DD which at the end limited the process of deliberation exclusively to a strict minority of the citizens.

9. On the difference between deliberative and participatory democracy on the basis of the type of personal engagement see for example MuTz (2006, 1-17). See also Tonella (2012). 
as able to reason with clarity and mutual respect on the merit of single political issues; possessing the ability of understanding one another in a complete way and taking decisions in the name of reasonable principles. It is also clearly possible to enlarge this notion of rationality by including also rhetoric ${ }^{10}$ and giving the proper importance to a-rational or irrational arguments in politics. They are very often used in political debates and can even manipulate the fairness of the deliberative process, as evidently happens in our day-to-day interactions. However, the ability to produce and detect these rhetoric forms and even to appreciate them should still be considered as a rational capability necessarily possessed by all the people involved in the deliberation. In fact, the epistemic assumption of an equal opportunity to express one's own opinions and to understand the arguments purported by others in order to enlarge one another's knowledge and competence does not lose any importance whether we adopt a rational choice framework, a dialogical or a rhetoric one. Put it differently, DD rests on a very precise and demanding notion of civil society and political audience which are deemed to evaluate, debate and take decision according to the principles of reason that everyone should possess and use.

\section{THE DISMISSED PREREQUISITES OF DELIBERATIVE DEMOCRACY}

Thus, the rational consensus which the process of deliberation should ultimately reach requires some unavoidable abilities possessed by all the people involved. The existing literature on DD has already stressed the necessity of several presuppositions for the theory to be feasible ${ }^{11}$, but here they will be considered exclusively the ones which flow from the notion of rationality it adopts and that, as will be proved, more directly take into account the relevance of education. It is possible to identify a list of rational oriented requirements implicit in the theory of deliberative democracy, which will be presented here also by illustrating the possible weaknesses they imply for the theory.

\subsection{Exhaustive information about the problems}

For a discussion to be effective all the people involved in it must know as much information as possible in order to offer their active contribution to the deliberation. With the term "information» I refer here to all the relevant data, news and knowledge indispensable to understand a problem and elaborate possible

10. For instance, CHAmbers (2009) particularly emphasises the importance of passions and rhetoric in the deliberative process, on this point see also GARSTEN (2011). On the notion of rhetoric, conceived in Aristotelian terms, as a constituent part of the deliberative process and at the same time as a cultivable ability see ARENAS Dolz (2013). Extremely useful is also the recent book NussBaum (2011).

11. See for instance the list presented by Crocker (2008, 317-330). 
solutions. The information has to be correct and fully accessible to everyone. Moreover, it has to be up-to-date in order to avoid anachronisms. The importance of providing this necessary information is, for instance, the basic trait of the method proposed by James Fishkin and his collaborators in the case of the deliberative polling (Fishkin, 2009) which, recognizing the necessity of this background condition, try to offer a good method for guaranteeing it. However, they focus strictly on small deliberative groups and not on democracy at large -as it should be done in order to render the theory systematic-. In case the information is missing, it is evident the risk of producing wrong arguments and taking inaccurate decisions. This precondition is indispensable to guarantee to the deliberation the condition of mutual acceptability, since everyone must have more than a clue of what the debate is about and of the main arguments in favour and against $\mathrm{it}^{12}$.

\subsection{Cultural background}

The information which each citizen should possess, however, has not to be thought as limited to news and everyday facts, but relates also to one's own cultural background. Indeed, in order to understand a fact or a theory in its complexity it is necessary to possess some indispensable means, namely a system of knowledge and values -at least at a minimum threshold. This threshold should be regulated in accordance to what José Ortega y Gasset labelled as the "principle of economy". Accordingly, the teacher should teach exclusively what an average student could apprehend, providing a general and overall view of all the most relevant disciplines of an epoch and culture- according to Ortega: Physic, Biology, History, Sociology and Philosophy (Ortega y Gasset, 2004-2010, IV, 545). If this precondition were not satisfied, then it would be impossible to think about any sort of aware and conscious public opinion. The public sphere would on the contrary be characterised by superficiality and recentism. As Ortega put it: «No vale hablar de ideas u opiniones donde no se admite una instancia que las regula, una serie de normas a que en la discusión cabe apelar. Estas normas son los principios de la cultura» (Ortega y Gasset, 2004-2010, IV, 417).

\subsection{Ability to use information and detect biased arguments}

Even when people do actually receive all the information they need in order to be active participants of the deliberative process, this does not mean that they are

12. This lack of information seems to significantly characterise the condition of many people. For instance, in the case of the U.S. democracy it has been demonstrated that still quite recently most of the American citizens are quite unaware of the main difference between republicans and democrats, the two main political parties of the country, see SOMIN (2004). The condition of political awareness and cultural knowledge of Italian citizens should not be considered less dramatic, as indicated by DE MAURO (2010). 
able to use this information correctly. In fact, the mere possession of a thing does not imply the ability of benefitting from this possession. This ability largely depends on the cognitive and personal functioning developed by single individuals ${ }^{13}$. This different degree of awareness and ability to manage a vast amount of information does not constitute a relevant problem only as far as the well known phenomenon of the "information overload" is concerned, but also in the case of the more basic ability of filtering and understanding an information. In our everyday life as citizens we get in touch with multiple sources and means which offer us particular perspectives on single problems, sometimes informing us neutrally, sometimes orienting our judgment in a more or less patent way. The ability to detect biased arguments is therefore linked to a minimal understanding of the principle of logic, but also to the awareness of the context in which this information is produced, of the target and the aim of the source. Evidently, this ability is not innate but must be trained. The risks if this condition were not taken into account by theorists of DD are that of producing senseless discussions which only reproduce well-known prejudices and folk-opinions, without digging into the questions.

\subsection{Complete and exhaustive ability to produce and understand sound arguments}

Evidently, a deliberation could be considered fair and equal only if every and each of its participants had an equal ability of understanding and influencing one another. This implies that, given the important and complicated issues at stake all the citizens must possess a very sophisticated level of competence regarding language skills, i.e. they have to be effective homines rhetorici. If this basic background condition is not satisfied, then the flaws for the theory are very risky. For instance, a small minority of people which possesses these skills at a higher level could influence in a charismatic way the majority of the population, independently of the merits of the questions; in addition, this influence could be intentionally produced for lobbying reasons; lastly, this influence would in any case condemn most of the people to a substantial inferior position, thus reinforcing and accentuating social inequalities within the deliberative process (Karpowitz, Raphael and Hammond, 2009). As a consequence, the deliberation would not change the opinions of the people involved in it, but would merely reproduce the existing statu quo as the final outcome of a seemingly rational consensus.

13. This argument can be highlight in a very clear way by considering the critics of Amartya Sen to Rawl's account of primary good. As SEN $(2009,66)$ writes: "The conversion of primary goods into the capability to do various things that a person may value doing can vary enormously with differing inborn characteristics (for example, propensities to suffer from some inherited diseases), as well as disparate acquired features or the divergent effects of varying environmental surroundings (for example, living in a neighbourhood with endemic presence, or frequent outbreaks, of infectious diseases). There is, thus, a strong case for moving from focusing on primary goods to actual assessment of freedoms and capabilities". 


\subsection{Impartial and keen attitude towards the problems at stake}

Another important condition for the debate to be fair is that all the people involved in it do offer arguments which can be accessible to everyone, not presenting egoistic or ideological reasons and discussing with the aim of reaching the best possible solutions for the general good. Moreover, they have to be willing to collaborate among one another, listening to opinions which differ from their own ${ }^{14}$ and persuaded of the correctness of the deliberation process as a fruitful method to respond to common problems. If it were not the case, then the deliberative process would lose all its heuristic dimension, and at the end it would only represent a rhetoric exercise and not a meaningful discussion. In fact no actual deliberation, in accordance to the definition already provided, will be held if people did not listen with an open-minded attitude and full respect to other's opinions and, in addition, if they were not strongly and deeply persuaded of the relevance of the political problems for their own life, sharing a common desire to find solutions together. Even if this last risk could seem to be avoided in the deliberations within strongly oriented groups, as in the case of political parties and movements in which the members share a common vision and defend common interests, this is only a false belief. Indeed, in this case the spectrum of political opinions is very limited, not taking into account opposite views which could even be stigmatized and labelled as heterodox. Therefore, if the deliberation within political parties could be useful for taking decision on problems related to inner questions, the same cannot be said regarding problems which affect the population at large.

\subsection{Time for acquiring and evaluate information}

Lastly, even if all the citizens possessed enough information, were able to use it correctly, were capable of use it to produce sounds arguments and did it for pursuing the general good, this would not mean that they would concretely have enough time to spend in acquiring and evaluating this information. The busy schedule of everyone's agenda represents a severe obstacle to the existence and development of all these deliberative conditions. To this basic problem it should also be added the lack of willpower of each single individual to spend a lot of efforts in political issues, what Aristotle, in the different context of in his Nicomachean Ethics, called akrasia.

The brief list presented here does not aim to constitute an exhaustive account of the difficulties related to the particular role played by rationality in the context of $\mathrm{DD}$, but rather to point out some of the more relevant ones in order to understand the reasons why the criticisms which flow from them must be unavoidably

14. About the factual difficult of this very important condition and the common preference to discuss within homogeneous environment see MUTZ (2006). 
considered by the defenders of the theory. In particular, in the next two paragraphs they will be considered two main objections which can fruitfully summarise the six points enlisted in this section of the paper.

\section{Deliberative DEMOCRACY AND PUbliC IGNORANCE}

The lack of information, of awareness of political circumstances and of sociohistorical contexts (conditions $a$ and $b$ ) could be comprised within the problem of the "public ignorance question". The problem has been explicitly posed with particular strength, among the other, by Ilya Somin (Somin, 2004, 2006, 2010) and Richard Posner (Posner, 2003). The argument can be summarised as follows: citizens are generally ignorant about the main political questions -Somin defends this statement by referring also to empirical data and surveys- and enable to reason properly due to cognitive and ethical deficits. Whereas this fact would not represent a problem within a traditional, or liberal concept of representative democracy, on the contrary it represents an insurmountable problem for the theory of DD -SO largely indebted to republicanism-. This is mainly due to the high requirements of rational deliberation already stressed in the first two paragraphs. According to Somin, not only the theory would be utopian but also dangerous since it would create a mere illusion of an inclusive and empowering theory of democracy but, in reality, it would demand so much that it would result completely unfeasible. At the end, according to this argument, DD at a large-scale view would be completely impossible, and could only work, to a certain extent, for local entities and private institutions ${ }^{15}$.

The "public ignorance question" evidently emphasises the effects of the lack of the basic rational requirements among citizens in relation to their knowledge and awareness, highlighting that they are deemed to intervene within public debate $e$ nativitate, but actually without possessing the necessary notions and information to do so. This argument could appear to be based on a negative, pessimistic and ultimately disputable account of society (Talisse, 2004). For instance, the argument could be countered by pointing out the growing level of alphabetisation of citizens in nowadays Western democracies, the increasing participation of the population in political forums, etc. Indeed, the data which could have been collected in relation to the time of Dewey or Ortega y Gasset revealed a completely different reality

15. "It is unlikely that either private- or public-sector decision making can fully achieve the high standards demanded by theories of deliberative democracy. But private-sector institutions will often come closer to doing so than democratic government. Moreover, reducing the size and complexity of government may make it easier for rationally ignorant voters to acquire the information they need to monitor those issue areas that remain under government control. In this way, reductions in government power can improve deliberation in the public sector as well as in the private sector» (SOMIN, 2010, 272). 
in comparison to our contemporary society ${ }^{16}$. However, the mere increase in the level of schooling or in the quantity of information received does not imply an increased level of political and civil literacy possessed by citizens who can still be totally ignorant and disinterested in political questions while very seriously committed to their specific niche of expertise. In addition, even if we naively assumed the absolute positive value of a growing alphabetisation, we should still consider the relevant differences in the degree and quality of this feature within our current society. Considering the case of Spain, for instance, the recent OECD Skills Outlook reports that, in a scale from 0 to 5 , only about $30 \%$ of the population possess a level of literacy proficiency of 3 or more, whilst among $60 \%$ just reach a 1 or 2 level ${ }^{17}$. Therefore, it can be said that not only the "political ignorance question" constitutes a relevant problem but that, combining this consideration with the strong inequalities which actually exist in the level of literacy, it is evident that DD needs also to face the problem of the effective contribution of citizens in the deliberation and of their differences in the degree of participation. The "political ignorance question" can be thought as related to the starting conditions and these are constituted both by the skills possessed by each individual and by the general environment which can offer an equal participation to everyone in the deliberation ${ }^{18}$. They characterise the level of rationality of the members of a deliberation and, very significantly, they directly influence the possibility of participating fairly in the deliberative process, as it will be shown in the next paragraph. So, after having presented this first problem, which depends on the way in which rationality is built, in the next section it will be considered the consequent problem related to way in which this rationality is expressed in the ongoing process of deliberation. This aspect is of great significance due to the fact that the theory of DD per se represents a dynamic and open model of government, not a static one.

\section{Deliberative DEMOCRACY AND THE ABILITIES' DEFICIT}

It is worth noting that the mere possession of the indispensable basic skills, of the abovementioned starting conditions, neither does constitute for the deliberation process a sufficient element for rendering it equal and fair, nor it guarantees the factual implementation of the deliberation. In the deliberative process, the rational abilities and the ways in which they are concretely expressed during the deliberation (conditions $c$, and $d$ ) are far more important than the mere potentiality of using

16. On the data concerning the Spanish situation at the time of Ortega y Gasset see in particular SCOTTON (2014, 611-614) and related bibliography.

17. OECD (2013). A lot of other significant data could have been pointed out thanks to this very useful study, which surely represents a reference point for comprehending the statu quo in relation to education and educative policies.

18. On the notion of "sustainable learning environments» see the interesting paper of MAROVAH (2013) 
them. Indeed, by using a terminology coined by Amartya Sen ${ }^{19}$, there is a significant gap between functioning -i.e. states of doing or being a person possesses and capabilities - i.e. the alternative combinations of functioning that could be actually and de facto achieved and that a person can therefore concretely develop during her life. As far as DD is concerned, this also means that in order to acquire the abilities a person needs she has to train and to invest enough time in doing this (condition $f$ ), and for taking part in the deliberation she must have the necessary occasions and possibilities that often are not guaranteed (condition $e$ ). In fact, as pointed out in §II, quite often people do not have the concrete possibility or will of spending a significant part of their everyday life in collecting and evaluating information on political issues (Ferejohn, 2008, 204-208). Moreover, even if it were the case, they probably would not be able to grasp the meaning of most of the issues at stake and of developing a personal and rational based opinion over them, due to the lack of logical, epistemological and conceptual abilities.

As far as DD is conceived as an inclusive model which not only potentially but also in practice calls for an active participation of all the citizens in the deliberation process, this represents an evident difficulty and weakness for the theory. This is what can be called the "abilities' deficit" which characterises our current society. Democracy, in fact, is not just a matter of means people have, of a superficial amount of shared knowledge they possess and enable them to be part of a sort of cultural industry, of a Halbbildung (Adorno, 1998). In such an apparent democracy everyone would have more or less the same possibility of accessing to a basic knowledge by being provided of a basic amount of information and, just for this reason, would be equal to all the other citizens - as the democratic rhetoric often purports $^{20}$. However DD has to satisfy a different and more demanding purpose, i.e. rendering possible a conscious understanding and a critical thinking in order to guarantee that, potentially and in practice, each citizen could bring a meaningful and useful contribution to a deliberation which always aims at reaching a rational consensus. Democracy, and in particular the deliberative model, is indeed seriously weakened when inequalities in the capabilities, not only in the means, are at stake. In fact, people who are more able than other to take part in the deliberation will end up by influencing others in a so powerful way that would invalidate the fairness and equality which deliberative democracy, in principle, defends. Even if the very deliberative process could be thought as an effective way of empowering the abilities of the citizens, this could be considered to be true only within smallscale scenarios, whereas it seems unlikely to currently happen in the ampler domain of the public sphere, rarely involved in a progressive and continuing process of

19. This distinction is maintained in a rigorous way by the philosopher in the vast majority of his works during the years, see for instance SEN (1992, 2005).

20. It will enormously exceed the purposes of this brief paper to pay the indispensable attention to the forceful criticisms to the notion and practice of current capitalistic democracies intriguingly presented, for instance, by ZIZEK (1989, 2008). 
political awareness. Moreover, the initial conditions of the deliberation and the inequalities concerning capabilities cannot but influence the development of any form of deliberation. Evidently, this dialectic among more talented and skilful people on the one hand and more inept on the other does correspond to a factual distinction in our society. But the innate character of this distinction can surely be disputed, insofar as it can be said to be a product rather than a cause of our current social relations. The abilities developed by individuals could in fact be said to depend not only on personal predispositions but also on the context in which a person lives and grows. And this second aspect is in particular the one which a fair education should contribute to determine for the flourishing of each and every single individual. As a consequence, a good means in order to ameliorate the abilities of people has often be rightly considered the educational system. As underlined also by some scholars of deliberative democracy ${ }^{21}$ education, and in particular a form of civic education, is crucial in constructing a society apt to adopt a deliberative account. For instance, as Martha Nussbaum wrote:

Nothing could be more crucial to democracy than the education of its citizens. Through primary and secondary education, young citizens form, at a crucial age, habits of mind that will be with them all through their lives. They learn to ask questions or not to ask them; to take what they hear at face value or to probe more deeply; to imagine the situation of a person different from themselves or to see a new person as a mere threat to the success of their own projects; to think of themselves as members of a homogeneous group or as members of a nation, and a world, made up of many people and groups, all of whom deserve respect and understanding (Nussbaum, 2006, 387).

The focus of Nussbaum in this case lies on primary and secondary education whereas, as already said, we consider more important for the purposes of this paper the succeeding stages of education and in particular university and the education for adults. They are those institutional stages which not only build but also maintain the political education and abilities of citizens over time, and for this reason have to be considered extremely important for the theory of DD.

\section{Deliberative DEMOCRACY AND UNIVERSITY. WHY AND WHAT}

The necessity of educating citizens to permit a genuine form of deliberative democracy is therefore a consequence of the unavoidable premises of the rationality which the theory requires. However, the use of education as a means for building a democracy composed by rational citizens has been strongly criticised by the proponents of the "public ignorance question", and with the same strength can be thought

21. From the classical study of MEYER (1977), to, for instance, the more recent work of GuTMANN (1999). 
to be denied by the possible defenders of the "abilities' deficit». Namely they refuse this point in the name of the following objections:

a) Impossibility of giving students enough information concerning political problems.

b) Inadequacy of the school and teaching system in general, as proved by the historical failure of education to provide an adequate level of rationality.

c) Limited period of time in which this civic education would be possible, namely only during the school-age.

d) Risk of promoting a hegemonic and propagandistic culture instead of a critical thinking ${ }^{22}$.

All these criticisms are very relevant in relation to the role of education in democracy, but they all can be effectively countered. Moreover, the discussion over these objections can reveal the major traits that university and adult education should possess in order to accomplish to its ethical and social purposes.

In relation to the first objection, it is important to notice that the rationality required by DD is not mainly concerned with the quantity and scope of the information possessed by each single person. Even if a large amount of information is a necessary condition for the theory to be feasible, it represents a secondary feature in comparison with the required ability of reasoning and providing effective arguments on the basis of the information available. Therefore, the most important aspect of education is not that of providing news and information, but rather of contributing to strengthen everyone's logical and argumentative skills. These, in fact, are indispensable in order to render citizens able to understand one another, to counter opposite arguments and to express further reasons in a persuasive and effective way. The curiosity towards acquiring new knowledge and the accuracy of a method to research the proper information are surely more important than the notions a person can acquire in a limited period of time. These are the traits which can provide the necessary stimulus to continue to research and acquire information in an independent and autonomous way. Evidently we do not live in a society which lacks information, but rather in which it is so dispersed and complicated that it could be difficult to be comprehended and understood. Only by stimulating the inner curiosity and interest of the student education can reach its aim of developing the individual's capabilities. This is also true in relation to university and adult education, where often programs are designed more in accordance with the interests of the teacher or the organizers of the course rather than with the ones of the students. In the words of Lorenzo Luzuriaga this would be the authentic pedagogy: "Ésta consiste en no ejercitar una actividad en el niño más que en tanto éste siente su necesidad, si no es instintiva, de tal suerte que el objeto de esta actividad cautive del niño -la única eficaz- debe ser, pues, atractiva: la materia a enseñar debe interesar al

22. This is a brief summary of the major criticisms presented by SOMIN (2004) to education as a means for developing a deliberative democracy. 
alumno" (Luzuriaga, 1961, 11). What Luzuriaga called "nueva pedagogía» is nowadays represented by the application and implementation of the capability approach to the realm of education (Boni and Walker, 2013). According to this approach, education and culture are deemed as necessary means in order to foster a concrete knowledge and communication among citizens. In this context, as Caroline Sarojini Hart put it: «The freedom to aspire and the functioning of aspiring both have important roles to play in human development. [...] This expansion takes account of the role of the freedom to aspire as a meta-capability and the functioning of aspiring as a precursor to many future capabilities. Developing an individual's capability to aspire is not a time limited process but an ongoing project that can be expanded and enhanced by removing barriers to this meta-capability" (Hart, 2013, 108).

As far as the second objection is concerned, the historical failures of education do not prove its inadequacy as a whole, but rather only in relation to a particular model of education. For instance, the interdisciplinary approach which consider each individual as an integrum and which suggests the existence of a minimal threshold in the learning process as the one proposed by Ortega y Gasset in his Misión de la Universidad can still represent a fruitful term of comparison. It is not a case that such an approach directly invited to an ethical role of university which, as he put it: "Necesita también contacto con la existencia pública, con la realidad histórica, con el presente, que es siempre un integrum y solo se puede tomar en totalidad y sin amputaciones ad usum delphini. La universidad tiene que estar también abierta a la plena actualidad; más aún: tiene que estar en medio de ella, sumergido en ella» (Ortega y Gasset, 2004-2010, IV, 566-567). If the growing level of schooling has not yet produced an increasing possession of deliberative skills this does not imply that a different curriculum could not be more effective than the one traditionally proposed. In particular, several scholars have recently been focusing on possible reformed curricula for implementing civic education in schools (McClave, 2000; Englund, 2000; Parker, 2002, 2006; Stitzlein, 2010; Brighouse and Unterhalter, 2010; Hanson and Howe, 2011; Glassman, 2011), and probably by looking to more or less recent proposals of education to citizenship -such as the one proposed by Ortega by also by other philosophers and pedagogues- ${ }^{23}$ a lot of progress can be done along this line. This is a question that the university should directly consider, rethinking its role within society, at least as far as its didactic and educative function is concerned. For instance, introducing within university more debated lessons and workshops, active seminars and participatory classes on a plurality of themes -also of immediate interest- could contribute to the purpose of enhancing deliberative skills within the university curricula. This should be done not only within humanistic faculties, but also within scientific ones, so to involve the whole university population.

23. Another interesting attempt to benefit from the theorisations of another contemporary philosopher for improving education for deliberative purposes has been carried out for instance by STANDISH (2013), with the theory of Stanley Cavell. 
In relation to the third objection, then, it has to be pointed out that it completely fails to take into account any form of adult and continuing education. The educative process, indeed, needs to be frequently revitalised and trained, not only during childhood and adolescence but throughout the entire life of a person in order to guarantee the maintenance and development of an adequate level of literacy and logical skills. As every single skill, also the ability of reasoning does not constitute a thing that can be acquired once and for all, but rather an habitus, which therefore has to be continually trained and exercised in the everyday life of a person. Given the patent impossibility of providing a schooling system which lasts for the entire life of an individual, it is important to focus on the other means people have to develop this habit, and among them it must be noticed the importance of continuing education provided directly by university or by other cultural institutions; but also the fundamental role played by media education, conceived both as knowledge of and by the media ${ }^{24}$. Indeed, the role of media in politics is ubiquitous, considering for instance that young people, according to recent studies, are exposed to 8 hours of media contents per day (Considine, 2009). Thus, to foster the ability of people to reason (Gee, 2013) and at the same time to provide them with useful information outside and after the formal schooling period, the role of the media is evidently of great importance, even if the media currently does not play an educative role as yet (Stoddart, 2014). Therefore, the media should play an educative role both in the method and in the contents offered to the users of these sources. In this case, the role of the public means of communication evidently needs to be implemented and reconceived accordingly (Habermas, 2006). It is here worth noting that university does have the opportunity to take an enormous part in this process by following this line of public communication and providing a growing amount of media contents, so to play a vital role within society.

This last consideration also reveals a possible way to counter the fourth objection previously presented, namely the risk that education, more than a critical framework, would lastly constitute merely a form of indoctrination and propaganda. Indeed, if university played a more relevant role in producing didactic media contents it would represent an authoritative source of information not dependent on parties' preferences or political aims, but rather primary relying on scientific bases. Generally speaking, it has to be pointed out that the variety of sources available to everyone renders quite impossible a hegemonic control of the information and opinions, given the variety and plurality of actors which produce information and orient the public opinion in the political public sphere. Once everyone is put in the condition of understanding, countering and producing proper and sound arguments, the risk of a hegemonic culture could in fact be relevantly mitigated. The method, the discipline and the continuity of a training in linguistic, logical and civic skills can be thought to constitute not only an indispensable prerequisite of DD

24. For an introduction on the importance of media education to foster the reasoning and argumentative skills of citizens see, for instance, the book by HOECHSMANN and POYNTz (2012). 
but also the most effective way to avoid the risk of a propagandistic culture, thus constituting a virtuous cycle.

To summarise the responses provided to the abovementioned objections, we can say that education can effectively be conceived as a concrete means thanks to which it would be possible to foster the rationality of citizens so to satisfy the basic requirements of deliberative democracy. However, to do so it would be indispensable to think about ad hoc curricula that, according to an aggregating view of interdisciplinary education, should offer to citizens, both during and after the school age -and in particular during their adulthood via university and continuing education- the instruments, methods and stimuli which are deemed as indispensable to develop critical and conscious thinking about the society in which they live. Only in this way deliberative democracy can maintain a positive and forwardlooking meaning and value. As pointed out, education has to be thought not merely as a possible way of providing knowledge and information, but also -and more relevantly- to develop the indispensable abilities to take part in the process of deliberation (McCowan and Unterhalter, 2013; Unterhalter, 2007). This feature emphasises the interdependence between school and society. Education can contribute to the development of capabilities not merely by increasing the level of alphabetisation, but also by empowering people who have lower functioning and possess less skills to develop their abilities, therefore rendering possible their active and vital contribution within democracy (Walker, 2006). As Amartya Sen wrote:

Democracy has complex demands, which certainly include voting and respect for election results, but it also requires the protection of liberties and freedoms, respect for legal entitlements, and the guaranteeing of free discussion and uncensored distribution of news and fair comment [...] Democracy is a demanding system, and not just a mechanical condition (like majority rule) taken in isolation (Sen, 1999, 10).

Interestingly enough, Sen attributes to the participation of people in the democratic process both an intrinsic, an instrumental and a constitutive value, that is to say that political freedom and participation per se not only contributes to the well-being of individuals (Nussbaum and Sen, 1993), but can render more meaningful the political decisions and at the same time can help society to improve its democratic character, by promoting a democratic participation by discussion. In order to achieve these capabilities, education plays a fundamental role both inside the school and outside it, since it provides the necessary functioning that can be implemented and used by citizens ${ }^{25}$. It constitutes an indispensable means through which society can reform itself by focusing on the individuals' rational traits so to foster a mature political debate. By adopting a capability approach framework

25. See Brighouse (2004). For an overall systematisation of Sen's approach in relation to the question of education, in particular in regard to the formal schooling and the characters the formation of students should have to contribute to shape future democratic citizens see DE CESARE (2013) and SAITO (2003). 
the gap which currently exists between the society in which DD is applied and the often dismissed requirement the same theory needs ${ }^{26}$ could be enormously mitigated. In particular this is true if we conceive citizens as people in constant formation, engaged in a dynamic process of flourishing as human beings and realisation of their own process of amelioration, and for whom the rational comprehension of the society in which they live play a vital role for their own lives. Such a concept of democracy directly focuses on the centrality of the individual, conceived in his own integrity, as an active and participative part of the society. Such an education cannot obviously be a result of DD, but rather its precondition. At the same time, it does not represent merely an instrument for enhancing a deliberative process, but rather it constitutes an end in itself which, as a side but fundamental effect, would render possible a genuine democratic participation.

\section{FINAL REMARKS}

In conclusion, the discussion on the necessary prerequisites of the theory of deliberative democracy in relation to the rationality required to all the citizens for a deliberation to be effective has clearly revealed the importance of a proper education towards logical, rhetorical and critical thinking, both during the formal schooling and in the adult age, and in particular through university and continuing education. This educational process has to be fostered both with traditional means and by looking at the innovation in the field of media education. Moreover, it has been demonstrated that this education cannot be conceived neither as a result of the deliberation process nor as a dispensable or unimportant condition for the model to be feasible. On the contrary, if this form of participative education were not enhanced a fruitful, equal and free deliberation oriented towards a rational consensus would lastly be impossible. Consequently, if deliberative democracy did not respond to this condition its deliberative character would evidently be dispatched - at least as far as the deliberation process is conceived as an effective and conscious engagement of people in politics. Within this context, the university has to accomplish to a fundamental ethical and social function which implies a constant and vital reform of itself and, consequently, of society. Indeed, this educative role would be realised only through a change both of the starting condition of rationality and of the development of the abilities acquired and fostered during the whole course of a human life. As a consequence, by accepting the DD's framework we are also obliged to consider University as engaged in a never-ending process of reform and implementation of deliberative skills. These conclusions, which evidently flow from what has been discussed in the course of this paper, point out the necessity of considering the normative character of the theory of DD.

26. Appropriately LEFRANÇOIS and ETHIER $(2010,273)$ indicate the existence of a significant gap between the ideal and the real of deliberative democratic theories and of a lack of realism of the model. 
Indeed, deliberative democracy cannot but appear a theory oriented towards the construction of a better society, at the same time operating as a de facto model in the real, current world. However, the inequalities that our current societies exhibit in relation to the skills, abilities, time, means, information and knowledge available to citizens constitute a dramatic limit and weakness for the theory. Evidently, this does not mean that deliberative democracy could not be usefully adopted to counter these inequalities, but at the same time it has to be clear that its mere application would not be effective and valuable without a concurrent change of what can be defined as the initial starting conditions. And this cannot be realised without a strong educative action. This would represent a social and moral change which can be helped and supported by university, in particular throughout the instruments and reforms which have been pointed out in the course of this article. University stills has a fundamental role to play within society, and this is especially true in an epoch of growing cultural homogeneity and massification. Evidently, this demand implies the ethical duty for university to reconsider the ways in which it transmits the products of that culture which, sometimes mechanically and routinely, it contributes to produce.

\section{BIBLIOGRAPHICAL REFERENCES}

ADORno, T. (1998) Theorie der Halbbildung in Gesammelte Schriften, Band 8; Darmstadt, Wissenschaftliche Buchgesellschaft, 93-121.

Arenas Dolz, F. (2013) Deliberative Democracy, Active Citizenship and Critical Culture: From Aristotle's Rhetoric to Contemporary Political Philosophy. Icono, 11 (1), 163-193.

BONI, A. and Walker, M. (2013) Universities and Human Development. A New Imaginary for the University of the XXI Century. London, Routledge.

Brighouse, H. (2004) Justice. Cambridge, Polity Press.

BRighouse, H. and UNTERHALTER, E. (2010) Education for primary goods or for capabilities?, in Brighouse, H. and Robeyns, I. (eds.) Measuring justice: Primary goods and capabilities. Cambridge, Cambridge University Press, 193-214.

Carcasson, M. and Sprain, L. (2012) Deliberative democracy and adult civic education. New direction for adult and continuing education, 135, 15-23.

Chambers, S. (2009) Rhetoric and the Public Sphere: Has Deliberative Democracy Abandoned Mass Democracy? Political Theory, 37 (3), 323-350.

Cohen, J. (1997) Deliberation and democratic legitimacy, in RHEG, W. and Bohman. J. (eds.) Deliberative democracy: Essays on Reason and Politics. Cambridge, MIT Press, 67-91.

Considine, D. M. (2009) From Gutenberg to Gates: Media matters. The Social Studies, 100 (2), 63-74

Crocker, D. A. (2008) Ethics of global development: Agency, capability, and deliberative democracy. Cambridge, Cambridge University Press.

De Cesare, T. (2013) Theorising democratic education from a Senian perspective. Studies in Philosophy of Education, 33, 149-170.

De Mauro, T. (2010) La cultura degli italiani. Roma-Bari, Laterza.

Dewey, J. (2008) Democracy and Education. New York, Courier Dover Publication. 
DryzeK, J. (2007) Theory, Evidence and the Tasks of Deliberation, in RosemberG, W. (ed.) Deliberation, Participation and Democracy. Can the people govern? London, Palgrave MacMillan.

Englund, T. (2000) Rethinking democracy and education: towards an education of deliberative citizens. Journal of Curriculum Studies, 32 (2), 305-313.

Ferejohn, J. (2008) Conclusion: The Citizens' Assembly model, in Pearse, H. and Warren, M. (eds.) Designing Deliberatibe Democracy. Cambridge, Cambridge University Press, 192-213.

Fishrin, J. (2002) Deliberative Democracy, in Adams, G. and Berzonsky, M. (eds.) The Blackwell Guide to Social and Political Philosophy. MA, Blackwell, 221-238.

FishKin, J. (2009) When the people speak. Oxford, Oxford University Press.

Garsten, B. (2011) The rhetoric revival in political theory. The annual review of political science, 14 (1), 159-180.

GEE, J. P. (2013) The anti-education era: Creating smarter students through digital learning. New York, Palgrave Macmillan.

Glassman, M. (2011) Is education ripe for a paradigm shift? The case for the capability approach. Education as Change, 15 (1), 161-174.

Gutmann, A. (1999) Democratic Education. Princeton, Princeton University Press.

Habermas, J. (1975) Legitimation Crisis. Cambridge ma, Beacon.

Habermas, J. (1998) Three normative models of democracy, in Habermas, J. (ed.) The inclusion of the other. Cambridge, MIT Press, 239-252.

Habermas, J. (2006) Political Communication in Media Society: Does Democracy Still Enjoy an Epistemic Dimension? The Impact of Normative Theory on Empirical Research. Communication Theory, 16, 411-426.

Hanson, J. and Howe, K. (2011) The potential for deliberative democratic civic education. Democracy \& education, 19 (2), 1-9.

Hart, C. S. (2013) Aspirations, Education and Social Justice. Applying Sen and Bourdieu. London-New York, Continuum.

Held, D. (2006) Models of Democracy. Stanford, Stanford University Press.

Hoechsmann, M. and Poyntz, S. (2012) Media literacies: A critical introduction. London, Wiley-Blackwell.

Honneth, A. (2013) La educación y el espacio público democrático. Un capítulo descuidado en la Filosofía Política. Isegoría. Revista de Filosofía Moral y Política, 49, 377-395.

Karpowitz, C.; Raphael, C. and Hammond, A. (2009) Deliberative Democracy and Inequality: Two Cheers for Enclave Deliberation among the Disempowered. Politics \& Society, 37, 576-615.

Lefrançois, D. and EThier, M. A. (2010) Translating the Ideal of Deliberative Democracy into Democratic Education: Pure Utopia? Educational Philosophy and Theory, 42 (3), 271-292.

Luzuriaga, L. (1961) El concepto de la nueva educación. Buenos Aires, Losada.

MarovaH, T. (2013) Citizenship education and human capabilities: lynchpin for sustainable learning environment and social justice. The Journal for Transdisciplinary Research in Southern Africa, 9 (3), 593-607.

McClave, H. (2000) Deliberative democracy and political education. Irish Educational Studies, 19 (1), 245-256. 
McCowan, T. and Unterhalter, E. (2013) Education, citizenship and deliberative democracy: Sen's capability perspective, in HedtKe, R. and Zimenkova, T. (eds.) Education for civic and political participation: a critical approach. London, Routledge, $135-154$.

Meyer, J. (1977) The Effects of Education as an Institution. American Journal of Sociology, 83 (1), 55-77.

Mutz, D. (2006) Hearing the other side: Deliberative versus participatory democracy. Cambridge, Cambridge University Press.

Nussbaum, M. (2006) Education and Democratic Citizenship: Capabilities and Quality Education. Journal of Human Development, 7 (3), 385-395.

Nussbaum, M. (2011) Creating Capabilities. The Human Development Approach. Cambridge, The Belknap Press.

Nussbaum, M. and Sen, A. (1993) The Quality of Life. Oxford, Clarendon Press.

OECD Skills Outlook 2013: First Results from the Survey of Adult Skills, oecD Publishing.

Ortega y Gasset, J. (2004-2010) Obras Completas. Madrid, Taurus.

Pateman, C. (1970) Participatory and Democratic Theory. Cambridge, Cambridge University Press.

PARKeR, W. (2002) Teaching Democracy: Unity and Diversity in Public Life. New York, Teachers College Press.

PARKer, W. (2006) Public Discourses in Schools: Purposes, Problems, Possibilities. Educational Researcher, 35 (8), 11-18.

Pateman, C. (2012) Participatory Democracy Revisited. Perspectives on Politics, 10 (1), 7-19.

Posner, R. (2003) Law, Pragmatism, and Democracy. Cambridge, Harvard University Press.

SAITO, M. (2003) Amartya Sen's capability approach to education: A critical exploration. Journal of Philosophy of Education, 37 (1), 17-33.

SARTORI, G. (1987) The theory of democracy revisited. Chatham, Chatham House.

ScotTon, P. (2014) Education to political life. Individual and society in the thought of Ortega y Gasset since the Meditaciones del Quijote (1914). History of Education and Children's Literature, IX (2), 603-622.

SEN, A. (1992) Inequality reexamined. Cambridge, Harvard University Press.

SEN, A. (1999) Democracy as a universal value. Journal of Democracy, 10 (3), 3-17.

SEN, A. (2005) Human rights and capabilities. Journal of Human Development, 6 (2), 151-166.

SEN, A. (2009) The Idea of Justice. Harvard, Harvard University Press.

Somin, I. (2004) Political Ignorance and the Countermajoritarian Difficulty: A New Perspective on the 'Central Obsession' of Constitutional Theory. Iowa Law Review, 87, 12871371.

Somin, I. (2006) Knowledge About Ignorance: New Directions in the Study of Political Information. Critical Review, 18 (1-3), 255-78.

Somin, I. (2010) Deliberative Democracy and political ignorance. Critical Review: A Journal of Politics and Society, 22 (2-3), 253-279.

Standish, P. (2013) Rethinking democracy and education with Stanley Cavell. Foro de Educación, 11 (15), 49-64.

Stitzlein, S. (2010) Deliberative democracy in teacher education. Journal of Public Deliberation, 6 (1), Art. 5.

Stoddart, J. (2014) The need for media education in democratic education. Democracy \& Education, 22 (1), 1-9. 
TAlisse, R. B. (2004) Does public ignorance defeat deliberative democracy? Critical Review: A Journal of Politics and Society, 16 (4), 455-463.

Talisse, R. B. (2009) Democracy and moral conflict. Cambridge, Cambridge University Press. Thompson, D. and Gutmann, A. (2004) Why Deliberative Democracy? Princeton, Princeton University Press.

Tonella, G. (2012) Politiche di Partecipazione. Dalla filosofia politica alla scienza delle politiche: politiche deliberative, partecipative e di rendicontazione. Padova, Cleup.

UNTERHALTER, E. (2007) Gender equality, education and the Capability Approach, in WALKER, M. and Unterhalter, E. (eds.) Amartya Sen's Capability Approach and Social Justice in Education. New York, Palgrave Macmillan, 87-107.

WALKER, M. (2006) Towards a capability-based theory of social justice for education policymaking. Journal of Education Policy, 21 (2), 163-185.

ZIzeK, S. (1989) The Sublime Object of Ideology. New York, Verso.

ZizeK, S. (2008) In Defense of Lost Causes. New York, Verso. 